University of Nebraska - Lincoln

DigitalCommons@University of Nebraska - Lincoln

Michigan Bovine Tuberculosis Bibliography and

Database

Wildlife Disease and Zoonotics

2002

\title{
Tonsillar Lesions in White-Tailed Deer (Odocoileus virginianus) Naturally Infected With Mycobacterium Bovis
}

\author{
M. V. Palmer \\ USDA, Mitchell.Palmer@ars.usda.gov \\ D. L. Whipple \\ K. L. Butler \\ S. D. Fitzgerald \\ C. S. Bruning-Fann \\ See next page for additional authors
}

Follow this and additional works at: https://digitalcommons.unl.edu/michbovinetb

Part of the Veterinary Medicine Commons

Palmer, M. V.; Whipple, D. L.; Butler, K. L.; Fitzgerald, S. D.; Bruning-Fann, C. S.; and Schmitt, S. M., "Tonsillar Lesions in White-Tailed Deer (Odocoileus virginianus) Naturally Infected With Mycobacterium Bovis" (2002). Michigan Bovine Tuberculosis Bibliography and Database. 74.

https://digitalcommons.unl.edu/michbovinetb/74

This Article is brought to you for free and open access by the Wildlife Disease and Zoonotics at DigitalCommons@University of Nebraska - Lincoln. It has been accepted for inclusion in Michigan Bovine Tuberculosis Bibliography and Database by an authorized administrator of DigitalCommons@University of Nebraska Lincoln. 


\section{Authors}

M. V. Palmer, D. L. Whipple, K. L. Butler, S. D. Fitzgerald, C. S. Bruning-Fann, and S. M. Schmitt 


\section{Short Communications}

Veterinary Record (2002) 151, 149-150

M.V. Palmer, DVM, PhD, D. L. Whipple, MS, Bacterial Diseases of Livestock Research Unit, National Animal Disease Center, Agricultural Research Service, USDA, Ames, IA 50010, USA K. L. Butler, DVM, PhD, S. D. Fitzgerald, DVM, $\mathrm{PhD}$, Animal Health Diagnostic Laboratory and Department of Veterinary Pathology, College of Veterinary Medicine, Michigan State University, East Lansing, MI 48824, USA C.S. Bruning-Fann, DVM, MS, Veterinary Services, Animal and Plant Health Inspection Service, USDA, East Lansing, MI 48823, USA S. M. Schmitt, DVM, Wildlife Disease Laboratory, Rose Lake Wildlife Research Station, Michigan Department of Natural Resources, East Lansing, MI 48823, USA

\section{Tonsillar lesions in white-tailed deer (Odocoileus virginianus) naturally infected with Mycobacterium bovis}

\author{
M. V. Palmer, D. L. Whipple, K. L. Butler, \\ S. D. Fitzgerald, C. S. BRuning-FanN, \\ S. M. SCHMITT
}

IN 1994, a free-living white-tailed deer (Odocoileus virginianus) in Michigan was diagnosed with tuberculosis caused by Mycobacterium bovis (Schmitt and others 1997). Subsequent surveys conducted by the Michigan Department of Natural Resources and Michigan State University Animal Health Diagnostic Laboratory identified an epidemic of $M$ bovis infection in free-living white-tailed deer in northeast Michigan (Schmitt and others 1997, O'Brien and others 2001). This represents the first known reservoir of $M$ bovis in free-living wildlife in the USA, and the first known epidemic of tuberculosis in white-tailed deer anywhere in the world.

Little is known concerning the pathogenesis of tuberculosis in white-tailed deer. In human beings, tuberculous granulomas within the lung and the tracheobronchial and mediastinal lymph nodes are described as a primary complex of lesions. In white-tailed deer, the medial retropharyngeal lymph node is the most common site for the development of lesions (Schmitt and others 1997, Palmer and others 2000, O'Brien and others 2001). If these lesions are viewed as one component of a primary complex, then lesions should also be expected in the palatine tonsil, which has efferent lymphatic drainage to the medial retropharyngeal lymph node. The medial retropharyngeal lymph node receives afferent lymphatic vessels from the tongue, floor of the mouth, hard and soft palate, gums, larynx and pharynx, caudal nasal cavity, maxillary and palatine sinuses, and tonsils (Saar and Getty 1975). This short communication describes a study designed to investigate the involvement of the palatine tonsils in white-tailed deer naturally infected with $M$ bovis.
As part of the effort to monitor tuberculosis in cervids in Michigan, white-tailed deer heads were voluntarily submitted by hunters to the Michigan Department of Natural Resources and examined for tuberculosis at the Animal Health Diagnostic Laboratory, Michigan State University. These were examined by careful dissection and inspection of the medial retropharyngeal, parotid, and mandibular lymph nodes. Occasionally, entire carcases were submitted for examination. Samples of suspicious lesions were collected for bacteriological isolation of $M$ bovis and microscopical analysis as described by O'Brien and others (2001). From over 10,000 submissions, 67 heads with gross lesions consistent with $M$ bovis infection were identified. The palatine tonsils were collected separately from all 67 cases and were processed for bacteriological isolation of $M$ bovis and microscopic examination, as described by Palmer and others (2000). Bacteriological isolation was considered positive if the organism was identified as a member of the Mycobacterium tuberculosis complex by colony and growth characteristics, biochemical analysis, and a DNA probe test (AccuProbe; GenProbe). Microscopic lesions were considered compatible with tuberculosis when granulomas containing acid-fast bacilli were seen. Granulomas that did not contain acid-fast bacilli were only considered suggestive of tuberculosis, and were not considered positive unless bacteriological culture yielded $M$ bovis.

Of the 67 deer heads with gross lesions, 41 (61 per cent) had histologic lesions in any tissue compatible with tuberculosis, or $M$ bovis was isolated from one or more tissues. Thirty-one of these 41 (76 per cent) had lesions compatible with tuberculosis in the palatine tonsil, or $M$ bovis was isolated from the palatine tonsil. In one additional case, the palatine tonsil was the only site of $M$ bovis isolation. Of the 31 deer with palatine tonsillar involvement, 28 (90 per cent) had involvement of one or both medial retropharyngeal lymph nodes.

The tonsillar lesions consisted of focal to multifocal and coalescent caseonecrotic granulomas, some with mineralisation of the central necrotic core. The granulomas were composed mostly of macrophages and multinucleated giant cells, with fewer lymphocytes and neutrophils. The granulomas were most common in the tonsillar crypt submucosa, and in some cases they extended through the crypt mucosa into the crypt lumen. The number of acid-fast bacilli within the lesions was highly variable. In most cases, there were low numbers of acid-fast bacilli but a few granulomas contained large numbers of acid-fast bacilli. 
Tonsillar lesions have previously been identified in tuberculous white-tailed deer, mule deer (Odocoileus hemionus), elk (Cervus elaphus subspecies canadensis) and red deer (Cervus elaphus) (Rhyan and others 1995, Rohonczy and others 1996, Lugton and others 1998, Palmer and others 2000). A study in cattle demonstrated tuberculosis in 30 of 32 heads from cows with delayed-type hypersensitivity to $M$ bovis (Cassidy and others 1999). In all 30 cases, lesions were present in the medial retropharyngeal lymph nodes. Palatine tonsillar involvement was present in 12 of 30 (40 per cent), but the palatine tonsil was not the only site of tuberculous involvement in any of the cases (Cassidy and others 1999).

The tonsils may play an important role in the pathogenesis of tuberculosis in ruminants (Lugton and others 1999). They are ideally located to sample bacteria entering through the oral or nasal cavities. Bacteria become trapped within tonsillar crypts, where follicle-associated epithelia actively take up microorganisms through specialised cells known as $M$ cells. Phagocytic cells below or between the M cells engulf microorganisms and process antigens, and in many cases the phagocytes containing the microorganisms migrate to draining lymph nodes (Lugton and others 1999). Specific evidence of the possible role of the tonsils in the pathogenesis of tuberculosis comes from experimental infection studies. Inoculation of $M$ bovis into the tonsillar crypts of red deer, white-tailed deer and cattle results in disease very similar to that seen in naturally infected animals (Mackintosh and others 1995, Palmer and others 1999a, b). Alternatively, tonsillar lesions may represent secondary sites of infection following haematogenous or lymphatic spread, or may be the result of sputum from the lungs containing $M$ bovis entering tonsillar crypts. Further research is needed to define the precise role of the tonsils in ruminant tuberculosis. Tonsillar lesions were once common in people with tuberculosis, and were thought to be a primary site of infection (Weller 1921, Anim and Dawlatly 1991). However, the prevalence of these lesions in people has decreased dramatically as the consumption of unpasteurised milk has become less common (Lugton and others 1999). Ingestion of $M$ bovis may, however, still be an important means of infection of ruminants.

The primary route of infection of human beings with $M$ tuberculosis is thought to be through aerosol exposure to microdroplets that pass through upper respiratory passages and localise deep within pulmonary alveoli (Riley and others 1959). Although aerosol exposure of the deep airways of the lung probably occurs in ruminants, frequent involvement of the medial retropharyngeal lymph nodes and tonsils suggests that the entrance of bacteria through the oral and nasal cavities may be equally important, and that these oropharyngeal tissues may play a role in the development of the disease. Further studies will help to clarify the pathogenesis of tuberculosis in domestic and wild ruminants and aid control of this important zoonotic disease.

\section{References}

ANIM, J. T. \& DAWLATLY, E. E. (1991) Tuberculosis of the tonsil revisited. West Africa Journal of Medicine 10, 194-197

CASSIDY, J. P., BRYSON, D. G. \& NEILL, S. D. (1999) Tonsillar lesions in cattle naturally infected with Mycobacterium bovis. Veterinary Record 144, 139142

LUGTON, I. W., WILSON, P. R., MORRIS, R. S. \& NUGENT, G. (1998) Epidemiology and pathogenesis of Mycobacterium bovis infection of red deer (Cervus elaphus) in New Zealand. New Zealand Veterinary Journal 46, 147156

LUGTON, I. W. (1999) Mucosa-associated lymphoid tissues as sites for uptake, carriage and excretion of tubercle bacilli and other pathogenic mycobacteria. Immunology and Cell Biology 77, 364-372

MACKINTOSH, C., WALDRUP, K., LABES, R., BUCHAN, G. \& GRIFFIN, F.
(1995) Intra-tonsil inoculation: an experimental model for tuberculosis in deer. In Tuberculosis in Wildlife and Domestic Animals. Eds F. Griffin, G. de Lisle. Dunedin, Otago University Press. pp 121-122

O'BRIEN, D. J., FITZGERALD, S. D, LYON, T. J., BUTLER, K. L., FIERKE, J. S., CLARKE, K. R., SCHMITT, S. M., COOLEY, T. M. \& BERRY, D. E. (2001) Tuberculous lesions in free-ranging white-tailed deer in Michigan. Journal of Wildlife Diseases 37, 608-613

PALMER, M. V., WHIPPLE, D. L. \& OLSEN, S. C. (1999a) Development of a model of natural infection with Mycobacterium bovis in white-tailed deer. Journal of Wildlife Diseases 35, 450-457

PALMER, M. V., WHIPPLE, D.L., PAYEUR, J. B., ALT, D. P., ESCH, K. J., BRUN ING-FANN, C. S. \& KANEENE, J. B. (2000) Naturally occurring tuberculosis in white-tailed deer. Journal of the American Veterinary Medical Association 216, 1921-1924

PALMER, M. V., WHIPPLE, D. L., RHYAN, J. C., BOLIN, C. A. \& SAARI, D. A (1999b) Granuloma development in cattle after intratonsillar inoculation with Mycobacterium bovis. American Journal of Veterinary Research 60, 310315

RHYAN, J., AUNE, K., HOOD, B., CLARKE, R., PAYEUR, J., JARNAGIN, J. \& STACKHOUSE, L. (1995) Bovine tuberculosis in a free-ranging mule dee (Odocoileus heminous) from Montana. Journal of Wildlife Diseases 31, 432435

RILEY, R. L., MILLS, C. C., NYKA, W., WEINSTOCK, N., STOREY, P. B., SULTAN, L. U., RILEY, M. C. \& WELLS, W. E. (1959) Aerial dissemination of pulmonary tuberculosis. American Journal of Hygiene 70, 185-196

ROHONCZY, E. B., BALACHANDRAN, A. V., DUKES, T. W., PAYEUR, J. B. RHYAN, J. C., SAARI, D. A., WHITING, T. L., WILSON, S. H. \& JARNAGIN, J. L. (1996) A comparison of gross pathology, histopathology, and mycobacterial culture for the diagnosis of tuberculosis in elk (Cervu elaphus). Canadian Journal of Veterinary Research 60, 108-114

SAAR, L. K. \& GETTY, R. (1975) Ruminant lymphatic system. In The Anatomy of the Domestic Animals. 5th edn. Ed R. Getty. Philadelphia, W. B. Saunders. pp 1024-1064

SCHMITT S. M FITZGERALD, S. D., COOLEY, T. M., BRUNING-FANN, C. S., SULLIVAN, L., BERRY, D., CARLSON, T., MINNIS, R. B., PAYEUR, J. B. \& SIKARSKIE, J. (1997) Bovine tuberculosis in free-ranging white-tailed deer from Michigan. Journal of Wildlife Diseases 33, 749-758

WELLER, C. V. (1921) The incidence and histopathology of tuberculosis of the tonsils. Archives of Internal Medicine 27, 631-660 